\title{
Job Attitude and Employee Performance: An Empirical Study of Non-Academic Staff of Bauchi State University Gadau Nigeria
}

\author{
Mohammed Inuwa ${ }^{1}$ \\ Munir Shehu Mashi ${ }^{2}$ \\ Isyaka Mohammed Salisu ${ }^{3}$
}

\author{
${ }^{1}$ Department of Business administration, Bauchi State University Gadau, Nigeria \\ ${ }^{2}$ School of Business Management, Universiti Utatra Malaysia, Malaysia \\ ${ }^{3}$ Department of Business Administration, Federal University Kashere, Gombe State, Nigeria \\ Correspondence: Department of Business administration, Bauchi State University Gadau Nigeria, Nigeria \\ Tel: +2347037099569, E-mail:inuwadem@gmail.com
}

Received: June 20, 2017

Accepted: July 22, 2017

Online Published: July 23, 2017

\begin{abstract}
Getting the best out of an employee has always been a major challenge an employer face in today's competitive environment. These might be however, connected to the fact that an employee is most dynamic and unpredictable aspect of business resources. It has therefore become imperative for organisations to realise the significance of an employee and also the device strategic means through which an employee can be influenced in order to develop positive job attitudes that can lead to higher performance. Hence, the study aims to examine the relationship between job attitude and employee performance by using the non-academic staff of Bauchi State University Gadau as unit of analysis. An aggregate of two hundred and seventy questionnaires were distributed non- academic staff of BASUG based on systematic random sampling and data collected was analysed using Statistical Package for Social Sciences (SPSS). The outcome of the analysis shows that there is positive and significant relationship between job attitude and employee performance. Also, the study is limited due to the fact that it adopts only two variables and concentrate in one institution only.Thepaper recommends that employers should prioritise important motivational factors that will bring about positive job attitude so as to achieve highest performance level of an employee. Furthermore, the study will serve as a policy guide to the management of the Nigerian Universities in areas relating to employee performance improvement through job attitude and it will also further make an impetus the field of organisational behaviour and human resource management.
\end{abstract}

Keywords: Job Attitude, Employee Performance, Organisational Efficiency.

\section{Introduction}

Performance level of an employed individual has constantly been a tasking challenge in management of an organisation, devising operational methods to motivate an individual employee to succeed and deliver qualitative job performance as well as surge the organizational competency level is the central objective of 


\section{Mohammed Inuwa, Munir Shehu Mashi and Isyaka Mohammed Salisu}

every business organisation (Lee \& Wu 2011). Ogbulafor, (2011) suggested that the deteriorating level employee performance in Nigerian tertiary institutions is fast becoming a serious threat to survival of universities in Nigeria which needs to be addressed urgently. This might as a result of government failure in developing countries like Nigeria to improve the skills and knowledge of their civil servants through effective human resource development programs the can boost employee performance as well as inability to exploit the capability of well experienced and trained employees (Tessema, Tesfayohannes-Beraki \& Tewolde 2015).

For that motive it is alleged that employee performance is contributory to organisational progression and lucrativeness (Poole, 2009). The employees are considered as the foremost business assets that expedite the regular accomplishments and tasks of an establishment (Mudah, Rafiki \& harahap 2014). Similarly, Oluwafemi (2010) proclaimed that managerial usefulness and competence hinge on how effective and efficient the employees in the organization are which is dependent upon their attitudes towards job. Mowday, Porter and Steers (2013), asserts that, most employees of today have a high degree of job dissatisfaction which create attitudes that are undesirable on the job and in turn degenerate their performance ability and that of their working place as well.

Therefore, such displeasure and unwanted behaviour on the job can be the cause of negative job attitude. Consequently it insinuates that employee's performance can be weighed by the extent to which an individual employee is pleased and satisfied on the job which will function as a catalyst on the behaviour and actions of the employee causing good behaviour that can enhance performance (Bhupatkar, 2012). Also, Wouter (2009) suggested that positive impressions that involves sensation of satisfaction on the work might bring about extreme and enhanced performance, specifically when viewing performance as being extensive than just task performance. It's also relatable to take note that a well and motivating pay bundle, working environment that is conducive and normal as well as even level of opportunities among employees can give birth to a good and likable job attitude while their mixture is also capable of being determining factor for enhancing the performance of employees in their workplace.

In view of these, the study aims to clarify the relationship between job attitude and performance of non-academic staff of Bauchi State University Gadau (BASUG) considering the role they played in supporting the academic staff and also running the day to day administrative activities of the University as stated by (Arikewuyo, 2012). Further, non-academic workforce of the university render a paramount part in the management of the university which create the necessity for them (non- academic staff) to be given the prospect to advance their human aptitude and secure more tutelage in order to be important in this 21st era (Oyeyemi, 2012). In support of the significance of the non-academic staff, Ajibade, (2012), also maintain that quest of educational superiority in the Nigerian institution of higher education is not only the obligation of the academic staff, but also the non- academic staff who carry out an indispensable part by taking charge of secretarial and clerical undertakings in order to solidify the right state that is essential for education to be impacted.

Despite the role the non - academic staff played, absence of clearly defined career development for nonacademic staff with low concern of government and management of Universities is believed to be a major cause of employee poor job attitude which leads to high turnover rate of support staff of public Universities in Nigeria (Bukar \& Timothy 2014). These however, give the non-academic staff the impression that their ambition and future career cannot be met by the University. Further, dissatisfaction and incongruity have over and over again ascended and developed from unsatisfied demands or unrestrained expositions of management prerogative between the non- academic staff, triggering rattle and in due course leading to lower performance of the non- 


\section{Mohammed Inuwa, Munir Shehu Mashi and Isyaka Mohammed Salisu}

academic staff thereby affecting the overall performance of the Universities (Adeniji and Adekunjo, 2010. Moreover, the subject of deprived funding by the government, which outcome brings about not only meagre salary scales but also untimely and inconsistent payment of the salaries with a wide disparity between the non-academic staff and the academic staff have also lead to unwanted job attitudes which tend directly affect the performance of the of the non- academic staff Nigeria seriously (Arikewuyo, 2012). However, this situation gives room for high rate of absenteeism, low job commitment and engagement which if not tackled can bring down the whole system to its kneel.

\section{Employee Performance}

Employee job performance has always been an important concern for managers of organisations (Kelidbari, Dizgah, \& Yusefi, 2011). Similarly, employee performance is key edifice of an organization therefore, aspects that place the grounds for high performance must be scrutinised critically by the organizations for them to succeed (Abbas \& Yaqoob, 2009). According to Lee, et-al, (2011), in a study titled "The effects of internal marketing, job satisfaction and service attitude on job performance among high-tech companies, has always been regarded as an important item in organizational management" defined job performance as workers' total performance in meeting the anticipated worth and achievement of tasks under the procedure and time requirements of the organization. Similarly Liao et-al, (2012), define job performance as the standard for advancements, redundancy, rewards, punishments, reviews and salary changes. It also satisfies the needs for employees to realize themselves. Ahmad and Khurram (2011), also argue that employee performance symbolises the broad belief of the personnel about their behaviour and contributions towards the achievement of the organization.

According to Ahmad and Shahzad (2011), apparent employee performance embodies the whole belief of the employee about their conduct and contributions to the accomplishment of the organization and further stated that compensation practices, performance evaluation and promotional practises as a determinant of employee performance. Similarly, Anitha, (2013) define employee performance as an indicator of financial or other outcome of the employee that has a direct connection with the performance of the organisation as well as its achievement, further revealed that working atmosphere, leadership, team and co-worker relationship, training and career development, reward programme, guidelines and procedures and workstation wellbeing as well as employee engagement are major factors that determine employee performance.

However, a study conducted by Alagarajal and Shuck (2015) aimed to discover prevailing viewpoints of organizational configuration and employee engagement in order to understand reasons associated with enhancing individual performance argue that employee performance can be enhanced through training and development. Furthermore, Thomas and Feldman, (2010) adopted measures of employee performance as core task performance, which includes in-role performance, safety performance, and creativity, followed by citizenship performance, categorised into both targets-specific and general organizational citizenship behaviours and lastly, counterproductive performance that consists of general counterproductive work behaviours, workplace aggression, substance use, tardiness, and absenteeism.

Therefore, employee performance brings about innovation performance and firm performance as a whole, in such a way that successful effort of fulfilled, inspired, and devoted human resources produce innovative ideas for new products or services and increase quality performance, operative performances, and client satisfaction directly (Sadikoglu \&Cemal, 2010). 
Job Attitude and Employee Performance: An Empirical Study of Non-Academic Staff of Bauchi State University Gadau Nigeria

\section{Mohammed Inuwa, Munir Shehu Mashi and Isyaka Mohammed Salisu}

\subsection{Job Attitude}

Job attitudes play a vigorous role in manipulating the work performances of employees' in organizations. Therefore, the necessity to recognise, measure, and boost employee attitudes is noteworthy for the organizations of today. As individuals have dispositions, so, too, do organizations. Organizations, like individuals, can be characterised and observed as rigid, welcoming, earnest, inventive, traditional or otherwise. Such qualities, as well, can serve as aspects to envisage attitudes and behaviours of the people within these organizations (George \& Jayan, 2013).

According to Allport (1935) define job attitude as a psychological or neural state for willingness, formulated through practice as well as applying instructions or vigorous influence on a person actions to every object and condition which is related to that particular situation. Ahmad, Ahmad and Syah, (2010) also define job attitude as paradigm that signifies a person's like or dislike as regards to different mode of behaviours. Liao et-al, (2012) define job attitude as a set of behaviour and judgements to work, and such behaviours and thoughts are redirected in form of work involvement and organizational commitment. Based on this definition, therefore job attitude can be viewed as actions and inactions of employee towards their work. Susanty, Miradipta and Jie (2013) define job attitude as a conviction or predisposition to behave in a certain way at the workplace as a result of an individual experience as well as personality. The way people behave in the workplace seldom relies on how an employee feels about his/her job which implies that understanding the work attitude of an employee is determined by the ones behaviour in workplace.

\subsection{Job Attitude and Employee Performance}

Harrison, Newman, and Roth (2006) also raise a very important question as to how crucial is job attitude for forecasting and comprehending employee performance as well as overall work role behaviour.

A conducted by Liao et-al, (2012) in a paper aims to discover whether there was an important correlation between work values, work attitude and job performance with the controlling role of leadership of employees in the green industry in Taiwan discover out that work attitude of employees in the green energy industry has a positive connection to job performance. Linz and Semykina (2008) in a research titled Attitude and performance: Analysis of Russian employees also finalise that job attitude is correlated to employee performance. In a study conducted by Susiana. Sulaiman and Almsafir (2013) with the aim of investigating the nexus between competency and attitude on attaining organisations vision define job attitude as an effective and core impetus of employee to accomplish their respective jobs successfully and further conclude that job attitude is believed to have a matching outcome on employee job performance.

Likewise, Pandey, et-al (2014) in an endeavour to explore employee's attitude to job related factors in rural intervention organisations in India finds out that there is a significant relation of employee productivity and factors which are related to the job. A positive attitude strengthens employee performance, thereby encouraging creativity and productivity. Therefore, if employees have more positive attitudes to the organization their productivity rises and, everything else being equal, the organization will be more resourceful and effective (George, et-al, 2012). Harrison, Newman, and Roth (2006) in a study aimed at drawing on the compatibility fundamentals in attitude and behaviour suggested that overall job attitude of an employee in highly integrated to performance of such employee.

In accordance with the study of Chih, Yang and Lu (2008) a positive work attitude of employee's results to higher job performance. Similarly, Wei and Chu (2008) in a paper titled Empirical study on the correlation among personality traits, work attitudes, service quality, Job performances and customers' satisfaction of a 


\section{Mohammed Inuwa, Munir Shehu Mashi and Isyaka Mohammed Salisu}

financial holding company in Taiwan conclude that job attitude has a significant relation to employee job performance. Moreover, Chu and Shi (2007) in a study aimed at exploring the relationship between work attitudes, work pressure, exit tendencies and organisational conflict came to the conclusion that work behaviour is linked employee performance. According to Hunter and Thatcher (2007) workers that passionately engaged to their work place develop a positive work attitude thereby increasing the employee's performance level.

\section{Hypothesis Development}

The hypothesis developed for the study include the:

H1: There is a positive relationship between job attitude and employee performance.

\subsection{Underpinning Theories}

The dependant variable which performance followed by job attitude as an independent variablewill be supported by Victor H. Vroom's Expectancy Theory (1964).

Expectancy theory maintains that the power of one's propensity to act in a certain way hinge on the expectation of the product of conduct or action as well as how attractive it is (Robbins \& Judge 2013). Expectancy theory is highlighted on the persuasion that employee work will result in performance and performance will lead to rewards (Vroom, 1964). However, expectancy theory is a cognitive procedure theory of motivation that is founded on the idea that employees perceive that there are relations between the effort they put out at work, the performance they accomplish from that effort, and the rewards they gain from their effort and performance, (Lunenburg, 2011). Further, Robbins \& Judge (2013) submitted that expectancy theory centres on three interactions that comprise effort- performance relationship, performance- reward relationship and personal goal relationship.

Base on the study, expectancy theory, therefore supports the assertion that the employee performs based on an expected outcome and depending on the outcome of such performance, the level of job attitude is determined. This implies that if an employee performance and expected result, it will enhance his/her job attitude thereby developing a positive attitude which will result to high level of performance of an employee. By implication higher rewards result in higher job attitude and increased performance level, whereas lower rewards demoralises an employee, thereby resulting to poor or negative job attitude which will bring about decreased performance (Ahmad, et-al, 2011; Lee, et-al, 2011; Liao et-al, 2012).

\subsection{Research Framework}

\section{Independent Variable}

\section{Dependent Variable}

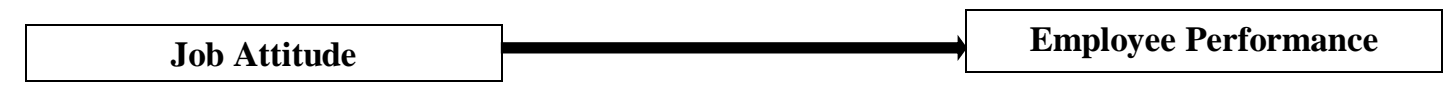

Adopted from the study of Liao et-al, (2012)

\subsection{Research Methodology}

The study followed quantitative method of gathering data which is done through questionnaire that was distributed to various respondents. A quantitative study as defined by Bhatti and Sundram (2015) is a way of calculating the data through the application of statistical methods and analysis and the outcome of the analysis represent numbers that further explains the propose remedy of a particular research problem A probability sampling design through the use of systematic random sampling is used by distributing questionnaires to the respondents. According to Greener (2008) a probability sampling is seen as a procedure 


\section{Mohammed Inuwa, Munir Shehu Mashi and Isyaka Mohammed Salisu}

that uses random selection so that every single unit of the population may have the chance of being chosen.

Hence, questions for the measurement of the variables were adopted from past researches. Both study variables are adopted and modified from the work of Liao et-al (2012), which was based on a five likert scale, ranging from agree to strongly disagree with Cronbach Alpha of 0.95 and six items that includes

Employee performance have a Cronbach Alpha of 0.95 and six items that includes: I understand the criteria of performance review of my organisation, I understand my job and how to carry it out, I am able to resolve unexpected schedules on time, I maintain good record of attendance in this organisation and I can carry out assigned duties effectively and efficiently.

While job attitude also havea Cronbach Alpha of 0.72 and six items that includes:Most of my hobbies are related to my job, I can fully exercise my strengths by working in this organisation, To me, my workplace reputation is my own reputation too, I can happily accept any task or responsibility assigned to me, I feel honoured when I tell others that I work in this organisation and I feel that my organisations' goals are similar to my personal goals.

\subsection{Analysis of Research Findings}

The research adopts Statistical Package for Social Sciences (SPSS) data analysis and test of reliability. A total sum of 270 questionnaires were given out to the respondents which are the non- academic staff of Bauchi State University Gadau Nigeria, out of which 256 were returned and 6 of the returned questionnaires were invalid due to incomplete and nonchalant responses which make the 250 as adequate and accurate and used for the analysis. This therefore constitute $98 \%$ of the total responses and on that basis it okay for running analysis as asserted by Sekaran (2003) that in a cross-sectional study $30 \%$ response rate can be accepted for a study.

Based on the response rate, the study shows that staff within the range of $30-39$ years constitute the major percentage of the workforce in the Univeristy which is $37.6 \%$, the might be because the management aims to recruit young people that will be able to deliver efficient and effective service that will help the Univeristy achieve its targeted vision and mission as stated in the academic brief (2012). Also, $35.6 \%$ of the staff fall within the age range of $40-49$ years which also shows that such staff within the range are experienced and capable to rendering qualitative service to the university, this also followed by staff within the ages of $20-29$ that constitute $15.2 \%$ of the workforce and lastly $11.62 \%$ which constitute of staff within the ages of 50 years and above. Therefore, the age distribution indicates that the university have a workforce of non- academic staff with sound mind and young age that capable of performing their assigned task effectively and efficiently thereby enhancing the performance of the institution.

Consequently, Inner consistency reliability test was employed which is believed to be a widely used technique for reliability test by most studies (Litwin, 1995) as presented below;

Table 1.0 Reliability test

\begin{tabular}{lccc}
\hline Variables & Responses & Number of items & Cronbach Alpha \\
\hline Job attitude & 250 & 6 & .784 \\
Employee performance & 250 & 6 & .704 \\
\hline
\end{tabular}

Expert in research suggested that reliability of 0.60 can be considered as average coefficient, whereas 0.70 could be regarded as high reliability coefficient (Nunnally, 1978; Sekaran \& Bougie, 2010; Sekaran 2003). Therefore, the study shows that the variables are greatly consistent. 
Job Attitude and Employee Performance: An Empirical Study of Non-Academic Staff of Bauchi State University Gadau Nigeria

Mohammed Inuwa, Munir Shehu Mashi and Isyaka Mohammed Salisu

Table 2.0 Descriptive statistics of variables

\begin{tabular}{lccc}
\hline Variables & Number & Mean & S/deviation \\
\hline Job attitude & 250 & 3.6720 & .55546 \\
Employee performance & 250 & 3.8227 & .68523 \\
\hline
\end{tabular}

The above shows that job attitude have a mean of 3.6720 and a standard deviation of .55546 while 3.8227 and .68523 represents the mean and standard deviation of employee performance. This therefore, depicts that employee performance have the highest mean score among the variables.

Table 3.0 Skewness and kurtosis of study variable

\begin{tabular}{lclll}
\hline Variables & Skewness & Standard error & Kurtosis & Standard error \\
\hline $\begin{array}{l}\text { Job attitude } \\
\begin{array}{l}\text { Employee } \\
\text { performance }\end{array}\end{array}$ & -0.253 & 0.154 & 0.525 & 0.307 \\
& -0.272 & 0.154 & 0.047 & 0.307 \\
\hline
\end{tabular}

In order to ascertain normality, Skewness and Kurtosis values for all variables were scrutinised. The standard threshold statistical values (z) for Skewness and Kurtosis are $<3$ and $<8$ respectively (Kline, 2005; Hair, Black, Babin, Anderson \& Tatham, 2006). This therefore, shows that the variables in question fall within the accepted threshold.

\section{Pearson Correlation}

Pallant (2002) asserted that items are formed by using single dichotomous and single continuous variable as measured by using correlation. However, Pearson correlation is seen as:

Table 4.0: Pearson Correlation

\begin{tabular}{lcc}
\hline Variables & EP & JS \\
\hline & & \\
EP & 1 & 1 \\
JA & $0.516^{* *}$ & 1 \\
\hline \multicolumn{3}{l}{}
\end{tabular}

The table above presents the correlation analysis of the study variable. It however, shows that the relationship between the dependant variable which is employee performance and independent variable which is job satisfaction are significant.

\section{Hierarchical Multiple Regression}

Pallant (2002) asserted that hierarchical regression falls under the three categories of multiple regression in which the rest of the two include simultaneous multiple regression and sequential multiple regression.Further, hierarchical regression.

Table 5.0 Summary of model

\begin{tabular}{lccc}
\hline Model & R & R square & R square adjusted \\
\hline $\mathbf{1}$ & 0.666 & 0.444 & 0.437 \\
\hline
\end{tabular}


Job Attitude and Employee Performance: An Empirical Study of Non-Academic Staff of Bauchi State University Gadau Nigeria

\section{Mohammed Inuwa, Munir Shehu Mashi and Isyaka Mohammed Salisu}

From the table above, it shows that the predictors which is the independent variable elucidates and discusses $44.4 \%$ of the dependant variable which is employee performance while $55.6 \%$ was explained by previous researches.

Table 6.0 Result of multiple regression (Employee performance as dependent variable)

\begin{tabular}{lllll}
\hline Model & Variables & B & t & Sig \\
\hline 1 & Job attitude & 0.312 & 4.442 & 0.000 \\
\hline
\end{tabular}

The result indicates that job attitude is also positively and significantly correlated to employee performance with $(\beta=0.312 \mathrm{t}=4.442 \mathrm{sig}=0.000)$. These further suggests that the study hypothesis is positive and significanceand therefore accepted according to Hair, Black, Babin, Anderson, \& Tatham (2006).

\subsection{Discussion}

The outcome of the research hypothesis also signifies that job attitude is positively related to employee performance portraying that a positive behaviour towards ones job is capable of boosting employee performance which is in consistent with previous research of (Newman, and Roth (2006), Liao et-al, (2012), Semykina (2008), Sulaiman and Almsafir (2013) \& Chih, Yang and Lu (2008) who also finds that an employee with positive work attitude on the job tend to have increased level of performance.

The result indicate that non- academic staff of Bauchi State University Gadau possess a positive and good job attitude which in turn lead to higher performance that enhances the overall efficiency and effectiveness of the institution in service delivery. Hence, the hypothesis is accepted. This implies that the study will provide relevant information to the management of the University as its regards to employee level of motivation and performance which also have positive impact one the overall performance of the University.

However, the study will aid the management of University in policy formulation regarding promotion, pay, training and other factors as it relates to the performance of employees in the organisation. Furthermore, the study will also aid the university to make strategic decision in areas of human resource development.

In line with theoretical contribution, the study is believed further contribute motivational theories is the sense that it combined expectancy a theory with factors like job attitude and employee performance. This simply implies that the study has contribute in the expansion on this theory as well as their applicability to the study variables which will help in understanding ways of enhancing employee performance by adopting proper ways that will bring about job satisfaction and positive job attitude.

\subsection{Conclusion, Limitations and Recommendations for Future Studies}

It is generally believed that employee performance is an indispensable component of organisational performance, therefore it is recommended that employers should prioritise important motivational factors that will bring about positive job attitude so as to achieve highest performance level of an employee.The study concludes that the non- academic staff of Bauchi State Univeristy are believed to have a positive job attitude and in that case the institution is able to harness its organisational resources in such a way such positive job attitude will bring about enhanced performance by every employee that will aid the institution in achieving it targeted goal and objectives timely and efficiently. The study also recommends that the University management should regularly device a means in which employees demand will be met on time in order to avoid job dissatisfaction which will have a negative impact on the performance of its employees and the organisation as a whole.

The study focus on the non-academic staff of Bauchi State University Gadau Nigeria which limit the rate of 
Job Attitude and Employee Performance: An Empirical Study of Non-Academic Staff of Bauchi State University Gadau Nigeria

\section{Mohammed Inuwa, Munir Shehu Mashi and Isyaka Mohammed Salisu}

responses.Therefore, the study is limited to only one Univeristy in the country despite the fact that there are many other Universities. Another major factor that limit the study is the fact that is it concentrates only on the non- academic staff without including the academic staff. Also, the study is limited to two variables which include job attitude as the independent variable with employee performance as the dependant variable implying that they the only variables tested in this study whereas other motivational variables can also be tested to ascertain level of employee performance.

\section{References}

Abbas, Q., \& Yaqoob, S. (2009). Effect of leadership development on employee performance in Pakistan. Pakistan Economic and Social Review, 269-292.

Adeniji, M. A., \& Adekunjo, O. A. (2010). The Role and Impact of Non-Academics Staff Union (NASU) in Two Nigerian Universities. Library Philosophy and Practice (e-journal), 332.

Ahmad, S., \& Shahzad, K. (2011). HRM and employee performance: A case of university teachers of Azad Jammu and Kashmir (AJK) in Pakistan. African Journal of Business Management, 5(13), 5249.

Ajadi, T. O. (2010). Private universities in Nigeria: The challenges ahead. American journal of scientific research, 7, 15-24.

Alagarajal, M., \& Shuck, B. (2015). Exploring Organizational Alignment-Employee Engagement Linkages and Impact on Individual Performance a Conceptual Model. Human Resource Development Review, 1534484314549455 .

Al-Ahmadi, H. (2009). Factors affecting performance of hospital nurses in Riyadh Region, Saudi Arabia. International Journal of Health Care Quality Assurance, 22(1), 40-54.

Allport, G. W. (1935) Attitudes. In: Murchison C. (Ed.), Handbook of social psychology Worcester, MA: Clark University Press, (798- 884)

Aluede, O., Idogho, P. O., \& Imonikhe, J. (2012). Increasing access to university education in Nigeria: Present challenges and suggestions for the future. In The African Symposium: An Online Journal of the African Educational Research Network (Vol. 3, No. 1, pp. 3-13).

Anitha, J. (2014). Determinants of employee engagement and their impact on employee performance. International Journal of Productivity and Performance Management, 63(3), 308-323.

Arikewuyo, M. O. (2009). University management and staff unions in Nigeria: issues and challenges. $S A-E d u c$. Journal, 3(1), 15-22.

Arogundade, B. B. (2010). Problems of Facilities in South-West Nigeria Universities and the way forward. Journal of Education Administration and Policy, 2(2), 039-043.

Avey, J. B., Reichard, R. J., Luthans, F., \& Mhatre, K. H. (2011). Meta-analysis of the impact of positive psychological capital on employee attitudes, behaviors, and performance. Human resource development quarterly, 22(2), 127-152.

Bakker, A. B., Tims, M., \&Derks, D. (2012). Proactive personality and job performance: The role of job crafting and work engagement. Human relations, 65(10), 1359-1378.

Benjamin, J. R., \& Cornell, C. A. (2014). Probability, statistics, and decision for civil engineers. Courier Corporation.

Bowles, S. (2014). Schooling in capitalist America: Educational reform and the contradictions of economic life. Haymarket Books. 
Job Attitude and Employee Performance: An Empirical Study of Non-Academic Staff of Bauchi State University Gadau Nigeria

\section{Mohammed Inuwa, Munir Shehu Mashi and Isyaka Mohammed Salisu}

Brief, A. P., \& Weiss, H. M. (2002). Organizational behaviour: Affect in the workplace. Annual review of psychology, 53(1), 279-307.

Collini, S. (2012). What are universities for? Penguin UK.

Demerouti, E., \& Cropanzano, R. (2010). From thought to action: Employee work engagement and job performance. Work engagement: A handbook of essential theory and research, 147-163.

Doug, A., Burton, N., Cuthill, I., Festing, M., \& Hutton, J. Playle, L. (2006). Why do a pilot study? www.je-lks.org/index.php/full-volumes/english-version-2005?task

Ekundayo, H. T., \& Ajayi, I. A. (2009). Towards effective management of university education in Nigeria. International NGO journal, 4(8), 342-347.

Erasto, k. (2014). Impact of information and communication technology on library operations and service delivery in private universities in Nigeria (Doctoral dissertation).

George, R., \& Jayan, C. (2013). Moderating Role of Organizational Culture on Job Attitude and Personal Effectiveness. Anvesha, 6(4).

Greener, S. (2008). Business research methods. BookBoon.

Hair, J. F. Jr., Black, W. C., Babin, B. J., Anderson, R. E., \& Tatham, R. L. (2006). Multivariate Data Analysis (6th Ed). US: Prentice-Hall PTR.

Harrison, D. A., Newman, D. A., \& Roth, P. L. (2006). How important are job attitudes? Meta-analytic comparisons of integrative behavioural outcomes and time sequences. Academy of Management journal, 49(2), 305-325.

Howard, A. D. (2009). An exploratory examination of positive and negative emotional attractors' impact on coaching intentional change (Doctoral dissertation, Case Western Reserve University).

Hulley, S. B. (2007). Designing clinical research. Lippincott Williams \& Wilkins, p. 168-169. www.2shared.com/document

Josephat, P., \& Ismail, A. (2012). Job and Work Attitude Determinants: An Application of Multivariate Analysis. International Journal of Human Resource Studies, 2(3), Pages-189.

Kagaari, J. R. (2011). Performance management practices and managed performance: the moderating influence of organisational culture and climate in public universities in Uganda.Measuring Business Excellence, 15(4), 36-49.

Kanungo RN (1982). Measurement of job and work involvement. Journal of applied

Kelidbari, H. R., Dizgah, M. R., \& Yusefi, A. (2011). The relationship between organization commitment and job performance of employees of Guilan Province social security organization. Interdisciplinary Journal of Contemporary Research in Business, 3(6), 555.

Kline, R.B. (2005). Principles and Practice of Structural Equation Modeling (2nd Ed.).

Krejcie, R. V., \& Morgan, D. W. (1970). Determining sample size for research activities. Educational Psychology Measures.

Liao, C. W., Lu, C. Y., Huang, C. K., \& Chiang, T. L. (2012). Work values, work attitude and job performance of green energy industry employees in Taiwan. African Journal of Business Management, 6(15), 5299-5318.

Linz, S. J., \& Semykina, A. (2008). Attitudes and performance: An analysis of Russian workers. The Journal of Socio-economics, 37(2), 694-717.

Locke, E. A., \& Latham, G. P. (1990). A theory of goal setting \& task performance. Prentice-Hall, Inc.

Malhotra, N. (1999). Marketing Research: An applied orientation (3rd Ed.). New Jersey: Prentice Hall. 
Job Attitude and Employee Performance: An Empirical Study of Non-Academic Staff of Bauchi State University Gadau Nigeria

\section{Mohammed Inuwa, Munir Shehu Mashi and Isyaka Mohammed Salisu}

Michael, A. (2006). A handbook of human resource management practice. Cambridge University Press, London. Mowday, R. T., Porter, L. W., \& Steers, R. M. (2013). Employee-organization linkages: The psychology of commitment, absenteeism, and turnover. Academic Press.

Muogbo, U. S. (2013). The Impact of Employee Motivation on Organisational Performance (A Study of Some Selected Firms in Anambra State Nigeria). The International Journal of Engineering and Science (IJES), 2(7), 70-80.

Nelson D.C \& Quick J. C. (2002). Organizational Behavior: Foundation, Realities and Challenges (4th Ed.). Australia: Thompson South-Western. New Jersey.

Ng, T. W., \& Feldman, D. C. (2010). Organizational tenure and job performance. Journal of Management, 36(5), $1220-1250$.

Nsofor, A. A. (2009). Influence of Expectancy Theory on Employees' Performance in Lagos State. Available at SSRN 1529246.

Ogbulafor C. (2011). Motivation and job performance of academic staff of state universities in Nigeria: the case of Ibrahim BadamasiBabangida University, Lapai, Niger State. International Journal of Business and Management, 7(14), p142.

Olalekan, A. M. (2008). University management and staff unions in Nigeria: issues and challenges. International Journal of Educational Management (IJEM), 5(1).

Ololube, N. P., Dudafa, U. J., Uriah, O. A., \& Agbor, C. N. (2013). Education for Development: Impediments to the Globalization of Higher Education in Nigeria. International Journal of Educational Foundations and Management, 1(2), 109-130.

Omolayo, B. O., \& Oluwafemi, A. A. (2012). Influence of Workers' Attitude towards Time and Work on Perceived Job Performance in Private and Public Sectors. Journal of Management and Strategy, 3(3), p2.

Pandey, A. C., Soodan, V., \& Jamwal, M. (2014). Attitute of Employees towards job factors: A study on rural interventions of Uttarakhand, India. Arabian Journal of Business and Management Review (Oman Chapter), 3(11).

Pinder, C. C. (2014). Work motivation in organizational behavior. Psychology Press.

Poole, E. (2009). Organisational spirituality-a literature review. Journal of business ethics, 84(4), 577-588.

Robbins, S., Judge, T. A., Millett, B., \& Boyle, M. (2013). Organisational behaviour. Pearson Higher Education $\mathrm{AU}$.

Sadikoglu, E., \&Zehir, C. (2010). Investigating the effects of innovation and employee performance on the relationship between total quality management practices and firm performance: An empirical study of Turkish firms. International Journal of Production Economics, 127(1), 13-26.

Sawyerr, A. (2004). Challenges facing African universities: Selected issues. African studies review, 1-59.

Schank, R. C., \& Abelson, R. P. (2013). Scripts, plans, goals, and understanding: An inquiry into human knowledge structures. Psychology Press.

Sekaran, U. \& Bougie, R. (2010). Research methods for business. A sill building approach (5th Ed.) John Willey: UK.

Tessema, M. T., Tesfayohannes-Beraki, M., Tewolde, S., \&Andemariam, K. HR Development and Utilization in the Public Sector.

Trunk Širca, N., Babnik, K., \& Breznik, K. (2013). Towards organisational performance: understanding human resource management climate. Industrial Management \& Data Systems, 113(3), 367-384. 
Job Attitude and Employee Performance: An Empirical Study of Non-Academic Staff of Bauchi State University Gadau Nigeria

\section{Mohammed Inuwa, Munir Shehu Mashi and Isyaka Mohammed Salisu}

Visagie, C. M. (2010). The relationship between employee attitudes towards planned organisational change and organisational commitment: an investigation of a selected case within the South African telecommunications industry (Doctoral dissertation, Cape Peninsula University of Technology).

Vroom, V. H. (1982). Work and motivation. Robert E. Krieger Publishing Company.

Wagner III, J. A., \& Hollenbeck, J. R. (2014). Organizational behavior: Securing competitive advantage. Routledge.

Watson, T. (2013). Management, organisation and employment strategy: new directions in theory and practice. Routledge.

Zikmund, W. G. (2000). Business Research Methods (6th edition). USA: Harcourt.

\section{Appendix}

\section{Appendices $A$}

\section{Research Questionnaire}

Section A: Demographic Data: Information about the profile of the respondent. Please Tick $\quad(\sqrt{ })$ in the box relevant to you.

\section{A. Age:}

What is your age range? [ ] Young: less than 20 years, [ ] Young: 20-29yrs, [ ] Old: 30-39yrs, [ ] Old: 40-49yrs, [ ] Old: 50yrs and above

\section{B. Gender:}

What is your gender? Male [ ] Female [ ]

C. Marital Status:

What is your marital status? [ ] Married, [ ] Single, [ ] Widowed, [ ] Divorced

D. Staff cadre:

What is your current cadre? Junior cadre [ ] senior cadre [ ]

\section{E. Educational qualification:}

What is your educational qualification [ ] Primary certificate [ ] Secondary certificate [ ] Diploma[ ] Degree[ ] Masters[ ] PhD

Section B: The statements in this section describes Job attitude. Kindly tick $(\sqrt{ })$ any option among the listed options to indicate your preferred answer to the questions.

Interpretations of the scales: Strongly Disagree (SD); Disagree (D); Neutral (N); Agree (A) and Strongly Agree (SA).

\begin{tabular}{|c|c|c|c|c|c|c|}
\hline & & SD & D & $\mathbf{N}$ & $\mathbf{A}$ & SA \\
\hline 1 & Most of my hobbies are related to my job & & & & & \\
\hline 2 & $\begin{array}{l}\text { I can fully exercise my strengths by working in this } \\
\text { organisation. }\end{array}$ & & & & & \\
\hline 3 & $\begin{array}{l}\text { To me, my workplace reputation is my own reputation } \\
\text { too. }\end{array}$ & & & & & \\
\hline 4 & $\begin{array}{l}\text { I can happily accept any task or responsibility assigned } \\
\text { to me. }\end{array}$ & & & & & \\
\hline
\end{tabular}


Job Attitude and Employee Performance: An Empirical Study of Non-Academic Staff of Bauchi State University Gadau Nigeria

Mohammed Inuwa, Munir Shehu Mashi and Isyaka Mohammed Salisu

5 I feel honoured when I tell others that I work in this organisation.

6 I feel that my organisations' goals are similar to my personal goals

Section C: The statements in this section describes Employee performance. Please tick $(\sqrt{ })$ any option among the listed options to indicate your preferred answer to the questions.

Interpretations of the scales: Strongly Disagree (SD); Disagree (D); Neutral (N); Agree (A) and Strongly Agree (SA).

\begin{tabular}{|c|c|c|c|c|c|}
\hline & SD & $\mathbf{D}$ & $\mathbf{N}$ & A & SA \\
\hline 1 & $\begin{array}{l}\text { I understand the criteria of performance review of my } \\
\text { organisation. }\end{array}$ & & & & \\
\hline 2 & I understand my job and how to carry it out & & & & \\
\hline 3 & I am able to resolve unexpected schedules on time. & & & & \\
\hline 4 & I maintain good record of attendance in this organisation. & & & & \\
\hline 5 & I can carry out assigned duties effectively and efficiently. & & & & \\
\hline 6 & $\begin{array}{l}\text { I am very conversant with the standard operating procedure of } \\
\text { my job. }\end{array}$ & & & & \\
\hline
\end{tabular}

\section{Copyrights}

Copyright for this article is retained by the author(s), with first publication rights granted to the journal. 